Zdzisław J. Kapera - Alexander Schick (red.) „When the Sun Rises Over the Earth, They Shall Bless" (4Q503). Professor Claus-Hunno Hunzinger Memorial Volume, The Qumran Chronicle 28-29 (2020-2021) (Kraków: The Enigma Press 2021) Ss. 392. PLN 80. ISBN 978-83-952021-9-3

\title{
Antoni Tronina
}

Katolicki Uniwersytet Lubelski Jana Pawła II ajtronina@gmail.com

https://orcid.org/0000-0003-3976-8271

W sierpniu 1990 r. ukazał się pierwszy zeszyt polskiego periodyku poświęconego archeologii Chirbet Qumran i rękopisom znalezionym w pobliskich grotach. Od tego czasu Kronika Qumrańska, pod redakcją jej założyciela Zdzisława Kapery, zdobyła znaczny rozgłos w świecie naukowym. Jest ona drugim po Revue de Qumran czasopismem specjalistycznym poświęconym wyłącznie odkryciom w Qumran. Najnowsze dwa roczniki, połączone w jeden tom, stanowią księgę pamiątkową ku czci zmarłego niedawno (3 I 2021) profesora Clausa-Hunno Hunzingera.

Hunzinger należał do zespołu pierwszych badaczy zwojów znad Morza Martwego. Zespół ten (tzw. scrollery team) powołał o. Roland de Vaux (w porozumieniu z ówczesnym dyrektorem Departamentu Starożytności Królestwa Jordanii Geraldem L. Hardingiem). W skład zespołu weszli trzej księża katoliccy (Józef T. Milik z Polski, Patrick W. Skehan ze Stanów Zjednoczonych oraz Jean Starcky z Francji), amerykański prezbiterianin Frank M. Cross, brytyjski anglikanin John Strugnell oraz inny Anglik, John M. Allegro, uznający się za agnostyka. Do tego zespołu dołączył w końcu roku 1954 niemiecki luteranin C.-H. Hunzinger, liczący zaledwie 25 lat.

Ponieważ nazwisko Hunzingera jest najmniej znane spośród pionierów prac nad zwojami, postanowiono uczcić jego pamięć osobną publikacją. Na apel Kapery odpowiedziało kilkunastu uczniów i przyjaciół zamarłego Profesora. Dzięki tej publikacji młodsi bibliści mogą się zapoznać z fascynującą historią odkryć oraz wkładem Hunzingera w początkowe badania nad treścią zwojów. Słowa cytowane w tytule księgi pamiątkowej pochodzą ze zbioru modlitw codziennych, odmawianych we wspólnocie qumrańskiej (4Q503). Dokument ten, złożony z 225 pergaminowych fragmentów, został wydany dopiero w roku 1982 przez Maurice’a Bailleta, który zastąpił Hunzingera po jego odejściu z zespołu.

Omawiana tu księga pamiątkowa składa się z 15 artykułów, zgrupowanych w pięciu rozdziałach tematycznych. Rozdział wstępny (s. 3-34) obejmuje cenne wspomnienia o Profesorze oraz jego bibliografię (James H. Charlesworth, A. Schick, Uwe Glessmer, T. Schramm). Dowiadujemy się z tych wspomnień ookolicznościach przyłączenia 
Hunzingera do zespołu badaczy zwojów z Qumran. Wzruszające są świadectwa o jego pasji naukowej i jeszcze większej miłości do Małgosi, którą poznał właśnie w Jerozolimie i dochował jej wierności aż do śmierci.

Pierwszy dział księgi nosi tytuł „Manuskrypty z Qumran” (s. 35-154) i obejmuje trzy artykuły renomowanych badaczy, nawiązujące do prac Hunzingera. Najpierw Kenneth Atkinson pyta kolejny raz o związek zwojów z pobliską osadą Chirbet Qumran („Are the Dead Sea Scrolls from Khirbet Qumran?”, 35-59). Różnorodność tego zbioru pism, porzuconych w okolicznych grotach, każe mu raczej przypuszczać, że tylko część zwojów powstała w tutejszej osadzie esseńskiej; większość dokumentacji wskazuje na inne wspólnoty, podzielające podobne przekonania. Nadchodząca inwazja wojsk rzymskich sprawiła, że ich księgozbiory ukryto w grotach z nadzieją ich odzyskania po powstaniu żydowskim.

Inny charakter ma obszerny artykuł Uwe Glessmera o kolejnych rekonstrukcjach Wielkiego Zwoju Psalmów („Reconstructions of the Great Psalms Scroll 11Q5”, s. 61-136). Rozpoczyna od nawiązania do pierwszych oględzin zwoju, jakich dokonał Hunzinger w roku 1957 w Ammanie. Następnie omawia kolejne próby zrekonstruowania zwoju 11Q5 - od Jamesa A. Sandersa (1965) do Ulricha Dahmena (2003) - i podaje własną propozycję odtworzenia treści dokumentu w 28 kolumnach. Co więcej, wyróżnia dwie fazy destrukcji zwoju: „stojącą” i „leżącą”. Momentem przełomowym miało być splądrowanie groty w IX wieku, poświadczone w ówczesnych źródłach.

Cennym dopełnieniem tego działu jest zestaw bibliograficzny najnowszych prac (2010-2020) nad identyfikacją i klasyfikacją rękopisów z Pustyni Judzkiej. Annette Steudel i Eibert Tigchelaar zawarli w tym zestawie informacje o mniejszych fragmentach - hebrajskich i aramejskich - które nie zmieściły się w oficjalnym wydaniu tekstów (Discoveries in the Judaean Desert 1-40). Ten krótki artykuł (s. 137-154) ułatwia młodszym badaczom dotarcie do aktualnych badań nad wieloma fragmentami zwojów, które dotąd uważano za „niezidentyfikowane”. Apendyks do tego artykułu traktuje nadto o fragmentach, które trafiły do rąk prywatnych kolekcjonerów, a które częściowo okazały się „podróbkami”.

Trzy następne artykuły tego festschriftu umieszczono pod wspólnym tytułem: „Esseńczycy”. Brian Capper podjął temat związany z Nowym Testamentem: „Men of Perfect Holiness: Essene Religious Virtuosity in Jerusalem and the Crowd Converted at Pentecost (Acts 2)" (s. 151-199). Hermann Lichtenberger zestawia teksty źródłowe o esseńczykach, zachowane w dziełach Filona i Józefa Flawiusza (s. 201-226). Wreszcie Rainer Riesner podejmuje szczegółowy temat „Bramy Esseńskiej” w Jerozolimie (s. 227-237), wspomnianej przez Flawiusza (De bello Iudaico 5,145).

Kolejny dział książki to „Archeologia Qumran”, zawarta w treści trzech artykułów. Claude Cohen-Matlofsky podjęła temat: „The Qumran Cemetery (-ies?) in Context”. Podtytuł wyjaśnia, że chodzi tu o praktyki pogrzebowe w hellenistycznej i rzymskiej prowincji Judaea-Palestina, w porównaniu z analogicznymi zwyczajami Nabatejczyków (s. 239-274). Drugim autorem w tym dziale jest Jacek Konik, polski archeolog z Warszawy. Podją on ciekawy temat, ujęty w pytaniu: „A Vibrant Place or a Remote CE” (s. 275-293). Okazuje się, że dzięki zaopatrzeniu w słodką wodę miejsca te były oazami życia. 
Ostatnim tekstem w dziele archeologii jest komunikat J. Randalla Price’a „The Mysterious massebot of Qumran” (s. 295-310). Wychodzi on również od wstępnych prac Hunzingera na terenie osiedla Qumran. W swoich własnych badaniach amerykański archeolog zwrócił uwagę na stojące kamienie, które przypominają kształtem biblijne maceby. Dokładne ich przeznaczenie nie jest na razie znane; w każdym razie stanowią one anomalię w praktykach esseńskich.

Ostatni dział tej interesującej książki nosi tytuł „Historia badań qumrańskich”. Zamieszczono tu dwa przyczynki polskich badaczy. Dariusz Długosz, kustosz z Musée du Louvre, omawia historię badań nad tajemniczym „Zwojem miedzianym” (3Q15). Oryginał zwoju, przechowywany w zbiorach Muzeum w Ammanie, został poddany konserwacji we Francji; jego faksimile natomiast znalazło się w Luwrze, w Dziale Starożytności Orientalnych, pod troskliwą opieką Długosza. Jego przyczynek, zamieszczony na końcu księgi pamiątkowej (s. 311-332), jest kopalnią wiadomości o Miedzianym Zwoju, od chwili jego odkrycia w trzeciej grocie aż po najnowszą rekonstrukcję jego treści.

Inny charakter ma wspomnienie Z.J. Kapery o archeologu izraelskim współczesnym Hunzingerowi. Magen Broshi (1929-2020), podobnie jak Kapera, zajmował się badaniem cmentarzy qumrańskich, toteż w artykule znajdziemy wiele ciekawych informacji o spotkaniach z tym niezwykłym człowiekiem, który odszedł z tego świata podczas „wielkiej pandemii", równie cicho i niezauważenie jak Hunzinger (s. 333-358).

Ostatni artykuł festschriftu, bogato ilustrowany, dotyczy „ossuariów w zbiorach niemieckich" (s. 359-383). Jego autor, Wolfgang Zwickel, profesor Uniwersytetu Gutenberga w Moguncji, od lat był związany z Hunzingerem, który zawsze akcentował rolę środowiska materialnego w badaniach nad Nowym Testamentem. Zwickel omawia tu szczegółowo dziesięć ossuariów, które z antykwariatów trafiły do Niemiec w latach 60. i 70. ubiegłego stulecia. Wszystkie one datują się z czasów Nowego Testamentu i stanowią ilustracje zwyczajów grzebalnych tej epoki. Końcowy indeks autorów (s. 385-392) ułatwia korzystanie z książki, która stanowi swoiste kompendium „qumranologii”.

$\mathrm{Na}$ koniec należy wyrazić serdeczną wdzięczność Z.J. Kaperze zarówno za staranne opracowanie omawianej książki, jak i za trzydzieści lat redagowania unikalnego periodyku naukowego, jakim jest Qumran Chronicle. Mam wrażenie, że czasopismo to jest bardziej znane za granicą niż w Polsce, gdzie ciągle brak należnego zainteresowania zarówno archeologią Chirbet Qumran, jak i rękopisami z pobliskich grot. Postulatem piszącego te słowa jest to, aby Qumran Chronicle znalazła stałe miejsce w bibliotekach wszystkich ośrodków teologicznych w Polsce, szczególnie na uniwersyteckich wydziałach teologicznych. 
